\title{
The biomarkers for genetic predisposition to some connective tissue autoimmune disorders in Belarus
}

\author{
Hanna Yatskiu \\ Institute of Genetics and Cytology \\ Minsk, Belarus \\ a.yatskiv@igc.by \\ Natalia Dostanko \\ Belarusian State Medical University \\ Minsk, Belarus \\ inill2@bsmu.by \\ Tatyana Kuzhir \\ Institute of Genetics and Cytology \\ Minsk, Belarus \\ t.kuzhir@igc.by
}

\author{
Elizabeth Siniauskaya \\ Institute of Genetics and Cytology \\ Minsk, Belarus \\ e.siniauskaya@igc.by \\ Victor Yagur \\ Belarusian State Medical University \\ Minsk, Belarus \\ yagur1@tut.by \\ Roza Goncharova \\ Institute of Genetics and Cytology \\ Minsk, Belarus \\ R.Goncharova@igc.by
}

\author{
Nataliya Nikitchenko \\ Institute of Genetics and Cytology \\ Minsk, Belarus \\ N.Nikitchenko@igc.by \\ Alexandr Sukalo \\ Belarusian State Medical University \\ Minsk, Belarus \\ childill1@bsmu.by
}

\begin{abstract}
Autoimmune disorders (ADs), such as rheumatoid arthritis (RA), juvenile idiopathic arthritis (JIA), systemic lupus erythematosus (SLE) complicated by lupus nephritis (LN) are the common and socially significant multifactorial diseases. The present study aims to highlight the contribution of certain gene variants involved in the inflammatory and autoimmune responses to predisposition to ADs and identify, if possible, the overlapping biomarkers. The study engaged the patients diagnosed with JIA, RA, SLE and $\mathrm{LN}$ as compared to controls genotyped for some SNPs at the IL6, IL6R and STAT4 loci using PCR-RFLP or real time PCR. Results have demonstrated the association between the ILG rs1800795 SNP and JIA/RA in the Belarusian population, as well as between the STAT4 rs7574865 and RA/SLE in adults, and SLE + LN in children suggesting its interference in the same pathogenic pathways of different ADs. The results show the association of the IL6 rs1800795 SNP with JIA and RA in Belarus. Evidence has been obtained that at least the STAT4 gene shares its risk potential between autoimmune diseases such as RA and SLE.
\end{abstract}

Keywords - gene polymorphisms, IL6, IL6R and STAT4 genes, rheumatoid arthritis, juvenile idiopathic arthritis, systemic lupus erythematosus

\section{Background}

Connective tissue autoimmune disorders (AD), such as rheumatoid arthritis (RA), juvenile idiopathic arthritis (JIA) and systemic lupus erythematosus (SLE) belong to common and socially significant diseases with serious consequences for patients in the form of cartilage and bone destruction, joint ankylosis in RA and JIA, and vascular injuries in SLE often complicated by kidney pathology, i.e., lupus nephritis (LN). According to current estimations, their prevalence varies from 5 to $8 \%$, and continues to increase steadily [1]. They arise from innate and adaptive immunity mistakes leading to selfdamaging immune response and develop due to interplay between environmental triggers and genetic predisposition [2]; the latter is in the focus of majority of modern investigations. Among genetic factors, HLA locus and nonHLA genes involved in immune and inflammatory responses are carefully studied in order to reveal molecular markers indicating increased susceptibility of their carriers to such diseases. In the past decade using genome-wide association studies, numerous AD-associated alleles (SNPs) has been established, most of the polymorphisms being located in noncoding regions of genome, which regulate gene expression modulating immune responses.

Studies concerning a genetic nature of different ADs face a number of problems, e.g., ethnic disparities in the implementation of the risk alleles [3]. Therefore, there is a need to examine the associations between known ADassociated gene variants and independent autoimmune diseases in the certain ethnogeographic conditions. The other problem is due to a minor contribution of individual SNPs to risk of developing ADs, when odds ratio (OR) does not exceed 1.5. Presumably, risk of developing the disease may be increased by multiple genes. Enhancement of the effects of individual SNPs during gene-gene interaction has been recently discussed using JIA in Belarus as an example [4], as well as reviewed in [5]. Herein, the results of a comparative study of the effects of several SNPs in three autoimmune diseases (RA, JIA and SLE) in the Belarusian population will be presented.

\section{Materials and Methods}

1) Study groups were recruited among patients of the 2 nd City Children's Clinical Hospital (Minsk) and the Republican Scientific and Practical Center of Transfusiology and Medical Biotechnology (Minsk). Participants of the study (or their relatives) signed informed consent in accordance with international standards for human research. Four groups were formed among children: patients diagnosed with JIA (1), SLE + LN (2); patients with articular syndrome (AS) other than JIA etiology (3), and patients without any inflammatory and autoimmune diseases as a control (4). Three groups were formed among adults: patients diagnosed with RA (1) and SLE (2), and clinically healthy donors as controls (3). DNA was extracted from blood samples (542 from children and 597 from adults) using ordinary phenol-chloroform method and genotyped for the IL6 rs1800795, IL6R rs 4845618 and rs2228145, as well as the STAT4 rs7574865 loci using PCRRFLP or real time PCR. The association between these SNPs 
and ADs was estimated using odds ratio and $95 \%$ confidential interval, i.e., OR $[95 \% \mathrm{CI}]$.

\section{Results and Discussion}

The main results obtained in the children's cohort indicate the association of JIA with the polymorphic variant rs1800795 of the IL6 gene in terms of both the C allele frequency (OR $[95 \% \mathrm{CI}]=1.43[1.07-1.94] ; \mathrm{p}=0.018)$ and the homozygous CC genotype frequency $(\mathrm{OR}[95 \% \mathrm{CI}]=2.39$ [1.48-3.86], $\mathrm{p}$ $=0.0008)$. At the same time, minor alleles in the polymorphic loci of the IL6R gene were found to be associated with AS of other than JIA origin. The risk potential was manifested by $\mathrm{CC}$ homozygotes $(\mathrm{OR}=2.07$ [1.13-3.78], $\mathrm{p}=0.00018)$ and the $\mathrm{C}$ allele $(\mathrm{OR}=1.63[1.20-2.22], \mathrm{p}=0.0018)$ at the $\mathrm{rs} 2228145$ locus, as well as TT homozygotes $(\mathrm{OR}=1.91$ [1.19-3.05], $\mathrm{p}$ $=0.02)$ and the $\mathrm{T}$ allele $(\mathrm{OR}=1.41[1.05-1.91], \mathrm{p}=0.023)$ at the rs4845618 locus. As to the STAT4 rs7574865 variant, we failed in detection of statistically significant differences between the JIA, AS and control groups. However, it was associated with developing SLE and LN in girls $(\mathrm{OR}=2.54$ $[1.00-6.42] \mathrm{p}=0.05$ for the genotypes GT $+\mathrm{TT}$ and $\mathrm{OR}=$ 2.14 [1.07-4.27] $\mathrm{p}=0.04$ for the $\mathrm{T}$ allele, respectively).

In the adult cohort, the CC genotype at the $I L-6$ rs 1800795 locus was associated with $\mathrm{RA}(\mathrm{OR}=1.52$ [1.02-2.27]; $\mathrm{p}=$ 0.0456). The studied polymorphic variants of the IL6R gene did not affect the sensitivity of the Belarusian population to RA and SLE. Statistically significant differences were found between the frequencies of the TT genotype and the minor T allele at the STAT4 rs7574865 locus in the RA and SLE patients as compared to controls, as well as in the SLE group versus RA. It was shown that these SNPs can serve as biomarkers of a predisposition to $\mathrm{RA}(\mathrm{OR}=2.36$ [1.04-5.38] $\mathrm{p}=0.04$ for the TT genotype), but they even more effectively predict the risk of SLE $(\mathrm{OR}=7,61[2.35-24.64] \mathrm{p}=0.0007$ for the TT genotype; OR $=2.83[1.53-5.22] \mathrm{p}<0.0009$ for the $\mathrm{T}$ allele).

\section{Conclusion}

The results show the association of the $I L 6$ rs 1800795 SNP with JIA and RA in Belarus. The STAT4 rs7574865 SNP increases susceptibility of adults to RA and SLE, and is associated with SLE and LN in children sharing risk effects between different autoimmune diseases.

\section{REFERENCES}

[1] G.S. Cooper, M. L.K. Bynum and E.C. Somers "Recent Insights in the Epidemiology of Autoimmune Diseases: Improved Prevalence Estimates and Understanding of Clustering of Diseases", J Autoimmun., vol. 33, pp. 197-207, Nov-Dec 2009.

[2] M. D. Rosenblum, K.A. Remedios, and A.K. Abbas "Mechanisms of human autoimmunity", J Clin Invest., vol. 125, pp. 2228-2233, April 2015.

[3] P.S Ramos, A.M Shedlock, and C.1. D. Langefeld "Genetics of autoimmune diseases: insights from population genetics", J Hum Genet., vol. 60, pp. 657-664, 2015.

[4] H.A. Yatskiu et al. "Genetic susceptibility to juvenile idiopathic arthritis in the belarusian population: gene-gene interactions analysis", Ecological genetics, vol. 17, pp. 65-76, 2019 [А.А. Яцкив и др. "Генетическая предрасположенность к ювенильному идиопатическому артриту в белорусской популяции: анализ межгенных взаимодействий”, Экологическая генетика. № 4, С. 63-74, 2019].

[5] T.D. Kuzhir "Polygenic nature of rheumatoid arthritis", Ecological genetics, vol. 17, pp. 77-90, 2019 [Т.Д. Кужир "Полигенная природа ревматоидного артрита ”, Экологическая генетика. № 4, С. 75-88, 2019]. 